\title{
Profile of bronchial responsiveness in children with respiratory symptoms
}

\author{
J B Clough, J D Williams, S T Holgate
}

\begin{abstract}
$A$ postal questionnaire inquiring into the presence of respiratory symptoms was sent to 3698 children aged 7 and 8 years. Those reporting either cough or wheeze were randomised, and a sample invited to attend for skin testing. A total of 192 symptomatic children, half of whom were atopic and half non-atopic, were randomly selected to enter the study.

All children performed and recorded best of three peak expiratory flow measurements twice a day and completed a 10 point respiratory symptom score card each day for one year. They also recorded all treatment taken and made a note of relevant life events.

Each child was seen monthly for general assessment and for measurement of nonspecific bronchial responsiveness to methacholine. Of the 192 children, 183 successfully completed the study. For six subjects 11 measurements of the provocation dose required to cause a $20 \%$ fall in forced expiratory volume in one second $\left(\mathbf{P D}_{20}\right)$ were available for analysis and on the remaining $177, \geqslant 12$ measurements.
\end{abstract}

The prevalence and degree of bronchial hyper-responsiveness $\left(\mathrm{PD}_{20}<6.4 \mu \mathrm{mol}\right)$ and its relationship to atopy was examined by comparing the percentage of members of each symptom group demonstrating bronchial hyper-responsiveness and the number of occasions on which they did so, and by comparison of minimum and median $\mathbf{P D}_{20}$ values. The range of bronchial responsiveness shown during the study period by each child was expressed as doubling doses of methacholine and compared between symptom groups.

Atopy and wheeze were both independently associated with an increased prevalence and greater degree of bronchial hyper-responsiveness when compared with non-atopy and cough respectively, all differences being significant at the 0.001 level. Thirty three per cent of subjects demonstrated a range of methacholine responsiveness of $>4$ and $13.4 \%$ of $>6$ doubling doses during one year.

Respiratory symptoms are common in childhood with as many as $25 \%$ of children aged 7-10 years being troubled by recurrent episodes of cough and wheeze. ${ }^{1}$ However, a diagnosis of asthma is made in less than half this number, ${ }^{2}$ despite the recent appreciation of asthma as a range of diseases with differing clinical mani- festations. This under diagnosis leads to under treatment and increased respiratory morbidity.

Many, but by no means all, asthmatic subjects demonstrate bronchial hyper-responsiveness $(\mathrm{BHR}),{ }^{3}$ as do a proportion of adult subjects suffering from respiratory symptoms in the absence of diagnosed asthma. ${ }^{4}$ However, because of its lack of specificity and low sensitivity for asthma, non-specific bronchial challenge has not proved to be a diagnostic test as was once hoped. ${ }^{5-8}$ Measurements of bronchial responsiveness may, however, serve as a useful laboratory tool, and as BHR may be potentially of importance in the pathogenesis of chronic obstructive pulmonary disease in adult life, ${ }^{9}$ this phenomenon merits the fullest investigation.

Much of the current knowledge regarding the relationship between bronchial responsiveness and other factors such as symptoms, measurements of airflow obstruction, and atopic status has been derived from studies that were cross sectional in nature, and assumptions often made on the basis of single measurements of reactivity. Whereas the short term repeatability of bronchial challenge testing is good, ${ }^{10-12}$ less is known about its longer term stability, but what evidence there is suggests that levels of bronchial responsiveness can vary appreciably with time and life events. ${ }^{13}$

In adult life there are several pulmonary pathologies that may produce overlapping symptom complexes. Thus when studying adult populations researchers are often tempted to choose highly polarised groups of mild stable asthmatic and strictly normal subjects for investigation. ${ }^{14}$ However, the study of these homogeneous groups can make it difficult to examine the determinants of airways responsiveness, and such studies may produce results which, when extrapolated to the population at large, are at odds with the findings of large, epidemiological surveys. In their work published in 1990, Pattemore et al highlighted the need for longitudinal studies which can assess the time related determinants and patterns of change of bronchial responsiveness. ${ }^{15}$

Our aim was to examine over one year a large, heterogeneous, randomly selected group of children with respiratory symptoms but not necessarily a diagnosis of asthma in order to examine both the prevalence and the severity of bronchial responsiveness and its relationship to atopy.

This work formed part of a community based longitudinal study, further details of which are reported elsewhere. ${ }^{16}$ 


\section{Subjects and methods}

SELECTION OF SUBJECTS

A postal questionnaire inquiring into the presence of respiratory symptoms in the past 12 months was sent to the parents of all children born between 1 July 1978 and 30 June 1980 registered on the practice lists of 86 primary care physicians working in five large local health centres. These numbered 3698 . The questionnaire was a brief and simple document that used three questions from a larger questionnaire described and tested for repeatability by Clifford et al. ${ }^{1}$ The relevant questions were: (1) Has your child had an attack of wheezing at any time during the last 12 months? (2) In the last 12 months, has your child seemed to cough more (or to get more coughs) than other children? (3) In the last 12 months, has your child woken at night with coughing for 3 or more nights in a row (apart from during the first 5 days of a cold)?

The positive responders were identified. For a child to be designated as having cough, it was necessary for them to have answered in the affirmative to one or both of the cough questions, but to have answered in the negative to that on wheeze. For a child to be designated as having wheeze, they must have given a positive reply to the wheeze question, and may have answered in the affirmative or the negative to the cough questions.

A random sample of children from each symptom group were tested by skin prick to three allergens: Dermatophagoides pteronyssinus, cat dander, and mixed grass pollen to ascertain their atopic status. The following four groups, each consisting of 48 children willing to enter a one year longitudinal study, were recruited: (i) atopic children with wheeze, (ii) atopic children with cough, (iii) non-atopic children with wheeze, and (iv) non-atopic children with cough. Further details of the selection and skin testing of subjects has been reported elsewhere. ${ }^{16}$

Table 1 Calibration of DeVilbiss nebulisers: variability and mean outputs

\begin{tabular}{|c|c|c|c|c|}
\hline $\begin{array}{l}\text { Nebuliser } \\
\text { No }\end{array}$ & $\begin{array}{l}\text { Mean output } \\
(m l)\end{array}$ & $S D$ & $\begin{array}{l}\text { Coefficient of } \\
\text { variation }\end{array}$ & $\begin{array}{l}\text { \% Mean } \\
\text { difference }\end{array}$ \\
\hline $\begin{array}{l}1 \\
\text { Day } 1 \\
\text { Day } 2\end{array}$ & $\begin{array}{l}0.00234 \\
0.00265\end{array}$ & $\begin{array}{l}1.21 \times 10^{-4} \\
1.40 \times 10^{-4}\end{array}$ & $\begin{array}{l}5 \cdot 17 \\
5 \cdot 27\end{array}$ & $11 \cdot 6$ \\
\hline $\begin{array}{l}2 \\
\text { Day } 1 \\
\text { Day } 2\end{array}$ & $\begin{array}{l}0.00235 \\
0.00257\end{array}$ & $\begin{array}{l}3.84 \times 10^{-4} \\
1.71 \times 10^{-4}\end{array}$ & $\begin{array}{r}16 \cdot 5 \\
6.6\end{array}$ & $8 \cdot 5$ \\
\hline $\begin{array}{l}3 \\
\text { Day } 1 \\
\text { Day } 2\end{array}$ & $\begin{array}{l}0.00256 \\
0.00285\end{array}$ & $\begin{array}{l}2.35 \times 10^{-4} \\
1.56 \times 10^{-4}\end{array}$ & $\begin{array}{l}9 \cdot 17 \\
5 \cdot 43\end{array}$ & $10 \cdot 1$ \\
\hline $\begin{array}{l}4 \\
\text { Day } \\
\text { Day }\end{array}$ & $\begin{array}{l}0.00238 \\
0.00240\end{array}$ & $\begin{array}{l}1.84 \times 10^{-4} \\
7.60 \times 10^{-4}\end{array}$ & $\begin{array}{l}7 \cdot 73 \\
3 \cdot 16\end{array}$ & 0.8 \\
\hline $\begin{array}{l}5 \\
\text { Day } 1 \\
\text { Day } 2\end{array}$ & $\begin{array}{l}0.00255 \\
0.00233\end{array}$ & $\begin{array}{l}1.44 \times 10^{-4} \\
1.23 \times 10^{-4}\end{array}$ & $\begin{array}{l}5 \cdot 64 \\
5 \cdot 27\end{array}$ & 8.6 \\
\hline $\begin{array}{l}6 \\
\text { Day } 1 \\
\text { Day } 2\end{array}$ & $\begin{array}{l}0.00222 \\
0.00210\end{array}$ & $\begin{array}{l}2.87 \times 10^{-4} \\
5.82 \times 10^{-5}\end{array}$ & $\begin{array}{c}12 \cdot 9 \\
2 \cdot 77\end{array}$ & $5 \cdot 4$ \\
\hline $\begin{array}{l}7 \\
\text { Day } 1 \\
\text { Day } 2\end{array}$ & $\begin{array}{l}0.00188 \\
0.00192\end{array}$ & $\begin{array}{l}1.60 \times 10^{-4} \\
1.22 \times 10^{-4}\end{array}$ & $\begin{array}{l}8 \cdot 55 \\
6 \cdot 35\end{array}$ & $2 \cdot 6$ \\
\hline $\begin{array}{l}8 \\
\text { Day } 1 \\
\text { Day } 2\end{array}$ & $\begin{array}{l}0.00175 \\
0.00182\end{array}$ & $\begin{array}{l}1.05 \times 10^{-4} \\
2.42 \times 10^{-4}\end{array}$ & $\begin{array}{l}6 \cdot 00 \\
13 \cdot 2\end{array}$ & 3.8 \\
\hline
\end{tabular}

Permission to carry out this study was granted by the Southampton University and Hospitals ethical subcommittee and written parental consent obtained for all stages of the study.

\section{METHODS}

The one year longitudinal study commenced in November 1987. At the start of the study each child was issued with a peak flow meter (Vitalograph) and instructed in its use. The children were asked to perform three peak expiratory flow (PEF) manoeuvres each morning and evening and to record the highest of the three readings. They also completed a symptom score card each day which inquired into 10 different upper and lower respiratory tract symptoms. On this card they also recorded all medications taken and made a note of relevant life events.

The children attended special clinics every four weeks for general assessment and for methacholine bronchial challenge. At the first visit each child's height was recorded and predicted values of forced expiratory volume in one second $\left(\mathrm{FEV}_{1}\right)$ and PEF based on height were calculated. A current drug history was taken, and children were asked not to use inhaled $\beta_{2}$ adrenoceptor agonist for six hours before each visit. All other antiasthma medication was withheld for 12 hours.

Methacholine challenge was performed using the method described by Yan et al. ${ }^{10}$ The method was modified in the following ways: a set of four nebulisers with known and consistent outputs was selected for each of the two investigators who performed the challenge testing as follows. Each investigator assessed the outputs of 10 nebulisers by weighing them before and after 10 activations, the initial content being $1 \mathrm{ml}$ of $0.9 \%$ sodium chloride. This procedure was repeated nine times. Variability in the output of the nebulisers was determined by the analysis of variance, in order to derive both the within-day and between-day coefficients of variation for each nebuliser. The eight nebulisers with the smallest coefficients of variation were subsequently used in the challenges. The within-day and between-day coefficients of variation for these nebulisers are shown in table 1 .

Solutions of methacholine, prepared in $0.9 \%$ sodium chloride, were made up for each nebuliser taking into account the mean output of each instrument such that the first delivered exactly $0.025 \mu \mathrm{mol}$, the second $0.1 \mu \mathrm{mol}$, the third $0.4 \mu \mathrm{mol}$, and the fourth $0.8 \mu \mathrm{mol}$ per puff. A fifth nebuliser was used to administer saline.

At the start of each visit, baseline $\mathrm{FEV}_{1}$ manoeuvres were performed to obtain two technically acceptable recordings within $100 \mathrm{ml}$. If the higher of these exceeded $60 \%$ of the predicted value for the child's height and age the challenge proceeded. The children were instructed in the use of the nebulisers. Once the investigator was satisfied that the child could perform the procedure correctly, two puffs of $0.9 \%$ sodium chloride were administered. 


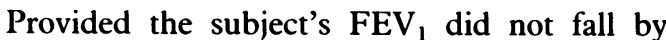
$>10 \%$ of baseline value, the procedure was repeated using incremental doses of methacholine from $0.025 \mu \mathrm{mol}$ to $6.4 \mu \mathrm{mol}$ until either the $\mathrm{FEV}_{1}$ fell by greater than $20 \%$ of baseline or the final dose was reached. On completing the challenge, $100 \mu \mathrm{g}$ of salbutamol was administered where appropriate by inhalation from a spacer device in order to restore airway calibre to basal levels.

If the initial baseline measurement of $\mathrm{FEV}_{1}$ was $<60 \%$ of predicted, then a reversibility test using $100 \mu \mathrm{g}$ of salbutamol inhaled from a spacer device was performed, with readings of $\mathrm{FEV}_{1}$ being made at five and 10 minutes after inhalation. Throughout the course of the study, all challenge testing was performed by two testers, each child being tested by the same tester on $>90 \%$ of occasions. A qualified physician was present at all times.

The repeatability of the challenge procedure was ascertained on a random subgroup of children. These children underwent methacholine bronchial challenge on two consecutive days, the tests being performed by the same investigator, at the same time of day.

\section{DATA ANALYSES}

All data were transferred to the University of Southampton mainframe computer, and were then checked against the original data source. All data were entered twice, and checked for

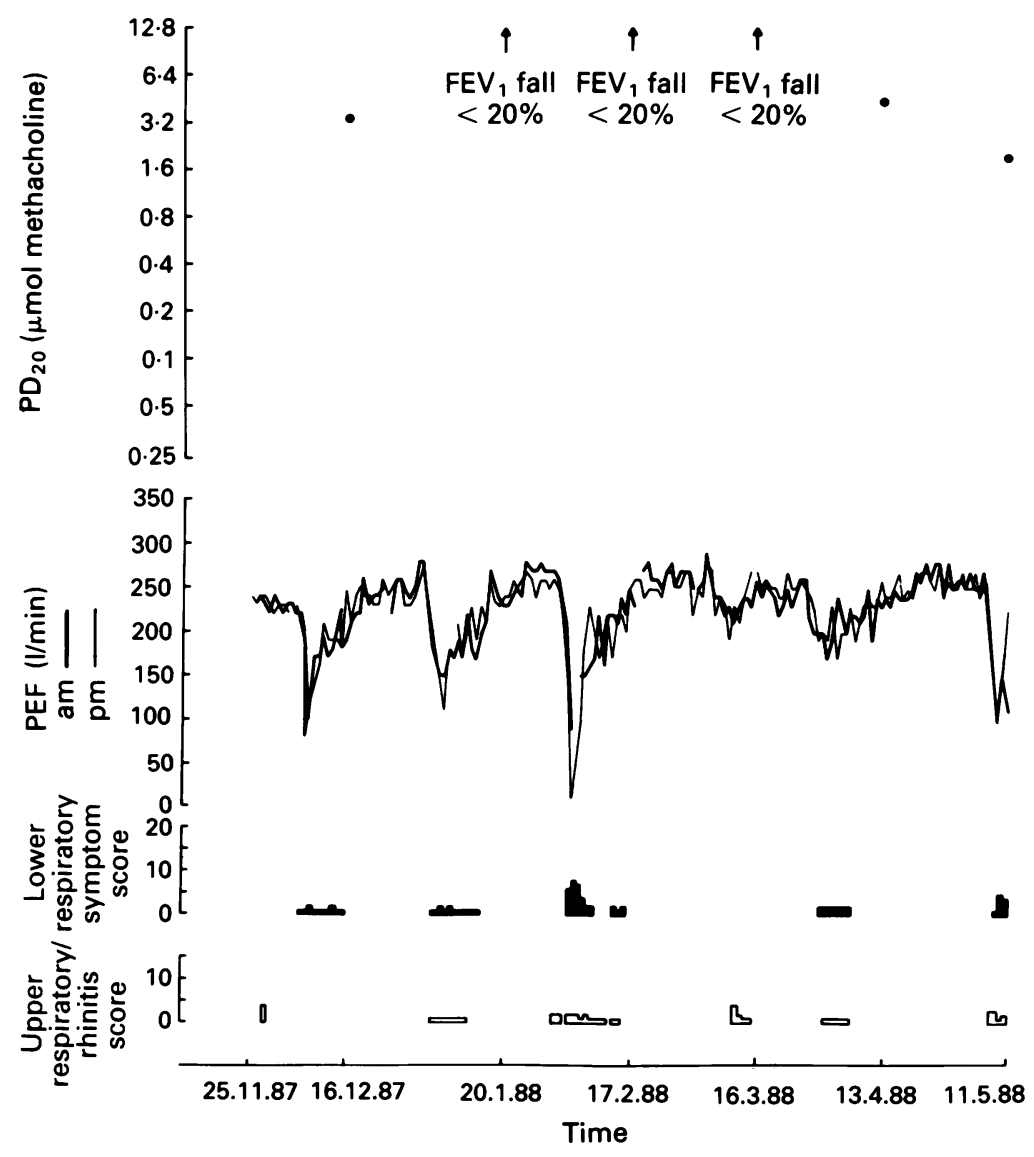

Figure 1 Graphical representation of data, collected over a period of six months, from a 7 year old atopic child with cough, showing respiratory tract symptoms and falls in PEF occurring in parallel, not accompanied by changes in methacholine responsiveness. accuracy. The Statistical Package for Social Sciences was used in the analyses.

In order to study the temporal relationship between the provocation dose required to cause a $20 \%$ fall in $\mathrm{FEV}_{1}\left(\mathrm{PD}_{20}\right), \mathrm{PEF}$, and symptoms, the data for each of the 192 subjects commencing the study were plotted graphically. An example is shown in fig 1 . Though the information gained from examination of these charts was necessarily subjective, it proved invaluable in directing further analysis, as manipulation of the data was difficult owing to its size $(>800000$ data points).

\section{Calculation of $P D_{20}$ values}

For each challenge the fall in $F E V_{1}$, expressed as a percentage of the highest value after saline, was plotted against the cumulative dose of methacholine on a logarithmic scale. The $\mathrm{PD}_{20}$ was estimated by log linear interpolation from the dose response curve. BHR was defined as a $\mathrm{PD}_{20}$ value of $<6.4 \mu \mathrm{mol}$ methacholine, in keeping with other studies of methacholine bronchial responsiveness. ${ }^{113}$ Values of $\mathrm{PD}_{20}$ beyond this point were regarded as being indeterminable. For each child the first methacholine challenge of the year was regarded as a teaching exercise and the result not used in the analyses. The subsequent $11(n=6)$ or $\geqslant 12(n=177)$ measurements for each subject were analysed.

For each of the four symptom groups, the following parameters were calculated: (1) The percentage of the subjects in the group who, at any time during the year, demonstrated BHR.

(2) The median number of times (maximum 12) the subjects in the group were hyper-responsive. (3) The minimum $\mathrm{PD}_{20}$ (by calculating the group median of the lowest recorded $\mathrm{PD}_{20}$ values for each subject). (4) The median $P_{20}$ (by calculating the group median of the median value of $12 \mathrm{PD}_{20}$ values for each subject). Kruskal-Wallis test was used on data from the four groups of subjects to establish the existence of a difference, and then Mann-Whitney U test was applied to combined data as shown in table 2 in order to assess the significance of that difference.

The range of bronchial responsiveness to methacholine during the study period was calculated for each child, expressed as doubling doses of methacholine, and the number of children demonstrating ranges of $\mathrm{PD}_{20}>4,>5$, and $>6$ doubling doses calculated. All subjects were included in this analysis, although many of them did not demonstrate BHR on some or all occasions of testing, and only $\mathrm{PD}_{20}$ values $<6.4$ $\mu \mathrm{mol}$ could be analysed.

Repeatability of the methacholine challenge test for a subgroup challenged on two consecutive days was expressed as the difference in relation to the mean for each of the pairs of values (coefficient of repeatability). ${ }^{13}$

\section{Results}

Altogether 183 of 192 subjects completed the 12 month long study, and of the nine who did not, three had performed 12 or more challenge procedures and were included in some analyses. 
Table 2 Percentage in each group ever demonstrating BHR, median number of occasions subjects demonstrated BHR, and group minimum and median $P D_{20}$

\begin{tabular}{|c|c|c|c|c|}
\hline Group & $\begin{array}{l}\text { \% ever } \\
\text { demonstrating } \\
\text { BHR }\end{array}$ & $\begin{array}{l}\text { Median No } \\
\text { occasions BHR } \\
\text { demonstrated }\end{array}$ & $\begin{array}{l}\text { Minimum PDIII } \\
(\text { (IImol methacholine })\end{array}$ & $\begin{array}{l}\text { Median PDIn } \\
\text { (ןmol methacholine) }\end{array}$ \\
\hline $\begin{array}{l}\text { Atopic+ wheeze } \\
\text { Atopic+ cough } \\
\text { Non-atopic+wheeze } \\
\text { Non-atopic + cough }\end{array}$ & $\begin{array}{r}89 \cdot 0 \\
35 \cdot 7 \\
30 \cdot 8 \\
7 \cdot 7\end{array}$ & $\begin{array}{r}11 \\
5 \\
4 \\
1\end{array}$ & $\begin{array}{l}0 \cdot 40 \\
1 \cdot 26 \\
1 \cdot 29 \\
5 \cdot 50\end{array}$ & $\begin{aligned} & 1.43 \\
> & 6.4 \\
> & 6.4 \\
> & 6.4\end{aligned}$ \\
\hline $\begin{array}{l}\text { Atopic } \\
\text { Non-atopic } \\
\text { Wheeze } \\
\text { Cough }\end{array}$ & $\left.\begin{array}{l}57 \cdot 1 \\
14 \cdot 3 \\
61 \cdot 5 \\
14 \cdot 3\end{array}\right\}^{*}$ & $\begin{array}{l}81^{*} \\
2\}^{*} \\
8\}^{*}\end{array}$ & $\begin{array}{l}0.821 \\
2.85 \\
0.64 \mid \\
2.85\end{array}$ & $\begin{array}{rl} & \left.5 \cdot 14\right|^{*} \\
> & 6 \cdot 4 \\
5 \cdot 04 & 1 \\
> & 6 \cdot 4\end{array}$ \\
\hline
\end{tabular}

${ }^{*}$ Mann-Whitney U test, $\mathrm{p}<0 \cdot 001$.

After exclusion of the first test, each child was subjected to 11-15 (median 13) methacholine challenges. Using the analysis of Bland and Altman, the coefficient of repeatability, calculated on data from the 14 children who performed methacholine challenge on two consecutive days, was $1 \cdot 3$ doubling doses (table 3 ).

The prevalence of BHR in each symptom group is shown in table 2. Prevalence figures are also given for all atopic subjects and non-atopic subjects, and for those with wheeze and cough collectively. BHR was positively associated with both atopy and wheeze (Mann-Whitney U test, $p<0.001$ ), and no interaction between these factors was demonstrated. Despite significant symptoms, only $7 \cdot 7 \%$ of the non-atopic subjects with cough demonstrated BHR on one or more occasions during the study period.

Table 3 Results of repeat methacholine challenge on two consecutive days in a subgroup of 14 children with $B H R$

\begin{tabular}{|c|c|c|c|c|}
\hline \multirow{2}{*}{$\begin{array}{l}\text { Subject } \\
\text { No }\end{array}$} & \multicolumn{2}{|l|}{ Day 1} & \multicolumn{2}{|l|}{ Day 2} \\
\hline & $\begin{array}{l}P D_{20} \text { ( } \mu \text { mol } \\
\text { methacholine) }\end{array}$ & $\lg _{2} P D_{20}$ & $\begin{array}{l}P D_{20} \text { (umol } \\
\text { methacholine) }\end{array}$ & $\lg _{2} P D_{20}$ \\
\hline $\begin{array}{r}1 \\
2 \\
3 \\
4 \\
5 \\
6 \\
7 \\
8 \\
9 \\
10 \\
11 \\
12 \\
13 \\
14\end{array}$ & $\begin{array}{l}1.020 \\
0.990 \\
1.041 \\
4.622 \\
1.566 \\
1.492 \\
2.400 \\
2.706 \\
0.033 \\
1.462 \\
0.351 \\
0.202 \\
3.994 \\
0.172\end{array}$ & $\begin{array}{r}0.028 \\
-0.014 \\
0.057 \\
2.205 \\
0.637 \\
0.578 \\
1.262 \\
1.435 \\
-4.913 \\
0.548 \\
-1.505 \\
-2.305 \\
1.996 \\
-2.538\end{array}$ & $\begin{array}{l}2.330 \\
0.870 \\
0.624 \\
2.848 \\
1.490 \\
1.660 \\
1.896 \\
3.400 \\
0.027 \\
2 \cdot 251 \\
0 \cdot 180 \\
0.118 \\
5.444 \\
0.210\end{array}$ & $\begin{array}{r}1.220 \\
-0.200 \\
-0.680 \\
1.508 \\
0.578 \\
0.734 \\
0.923 \\
1.766 \\
-5.235 \\
1.170 \\
-2.471 \\
-3.073 \\
2.441 \\
-2.249\end{array}$ \\
\hline
\end{tabular}

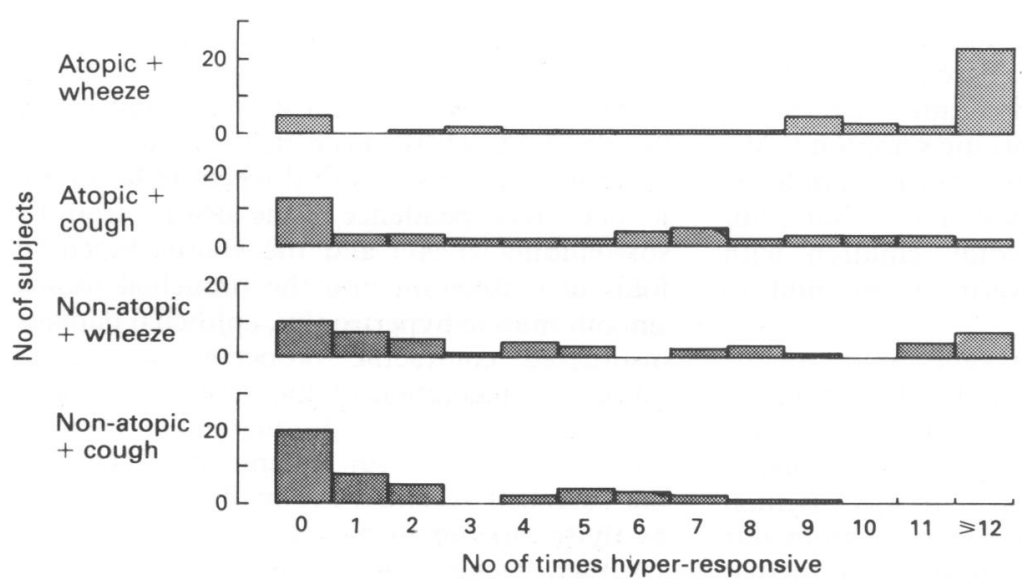

Figure 2 Frequency distribution of the number of times (maximum 12) that subjects in each of the four symptom groups demonstrated bronchial hyper-responsiveness to methacholine.
Figure 2 represents, for each symptom atopy group, the frequency distribution of the number of occasions each child exhibited hyperresponsiveness to methacholine. The median number of occasions on which each subject demonstrated BHR during the year was calculated, and the median for each group is shown in table 2. Subjects with atopy and those with wheeze demonstrated BHR on significantly more occasions when compared with those who were non-atopic and those with cough respectively (Mann-Whitney U test, $p<0 \cdot 001$ ). No interaction was demonstrated between atopy and wheeze. The frequency distribution of median $\mathrm{PD}_{20}$ in the four groups is shown in fig 3. While the median $P_{20}$ generally falls in the hyper-responsive range for the atopic children with wheeze, no child who was non-atopic with cough demonstrated a median $\mathrm{PD}_{20}$ of $<3 \cdot 2$ $\mu \mathrm{mol}$ methacholine. The group medians of the minimum $\mathrm{PD}_{20}$ and of the median $\mathrm{PD}_{20}$ for each subject in that group are shown in table 2 . Both atopy and wheeze were associated with lower $\mathbf{P D}_{20}$ values when compared with nonatopy and wheeze respectively (Mann-Whitney $\mathrm{U}$ test, $\mathrm{p}<0.001$ ).

The frequency distribution of the range of values of $\mathrm{PD}_{20}$ demonstrated by each subject over the course of 12 months, expressed in doubling doses of methacholine, is shown in fig 4. $P_{20}$ methacholine varied by $>4$ doubling dilutions in $61(32.8 \%)$ subjects, by $>5$ doubling dilutions in $37(19 \cdot 9 \%)$, and by $>6$ in $25(13 \cdot 4 \%)$, showing that over 12 months methacholine responsiveness was not a stable phenomenon in this group, and that measurements in individuals could span the full range of doses used in testing.

\section{Discussion}

This study demonstrates a clear relationship between BHR and the presence of both atopy and the symptom of wheeze in a large group of symptomatic subjects in whom bronchial responsiveness was measured repeatedly over the course of one year. Bronchial responsiveness was shown to vary considerably in individuals over this time, almost $33 \%$ of subjects demonstrating $>4$ doubling dose variation in $\mathrm{PD}_{20}$, although short term repeatability was good.

The children entered into this study were heterogeneous with regard to both symptom type and symptom severity. Many young children experience recurrent cough in the absence of wheezing, and the significance of this 


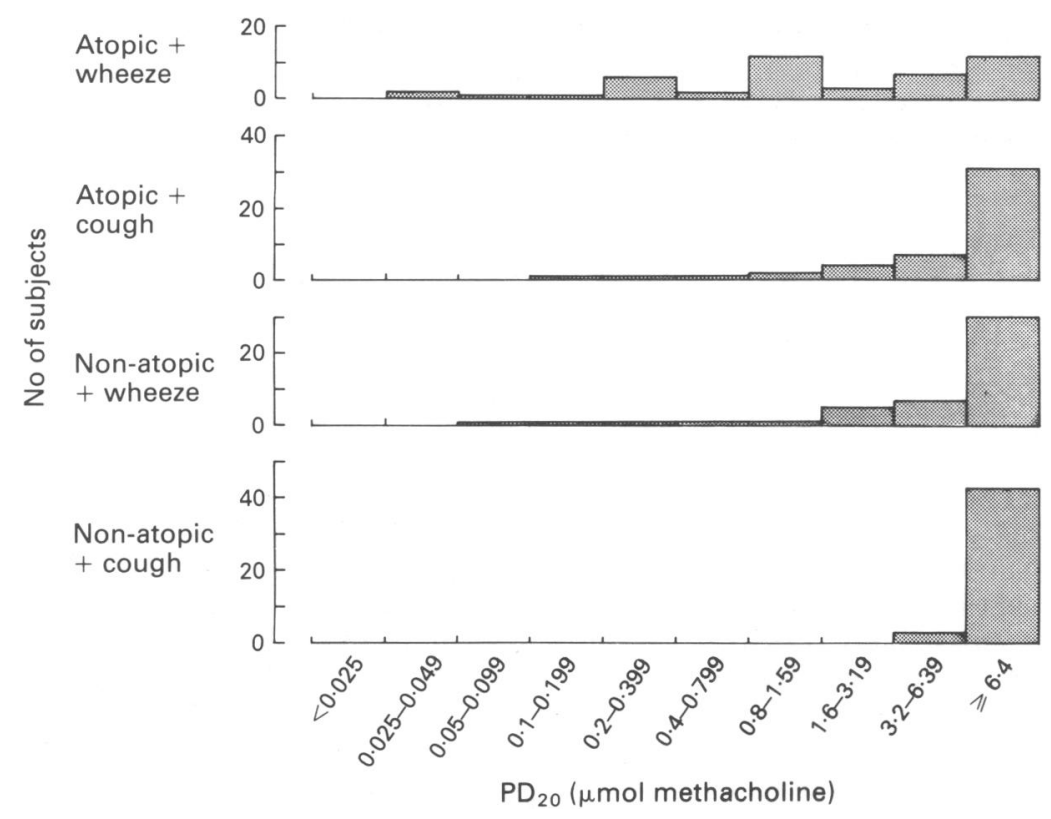

Figure 3 Frequency distribution of median $P D_{20}$ over 12 months by symptom group.

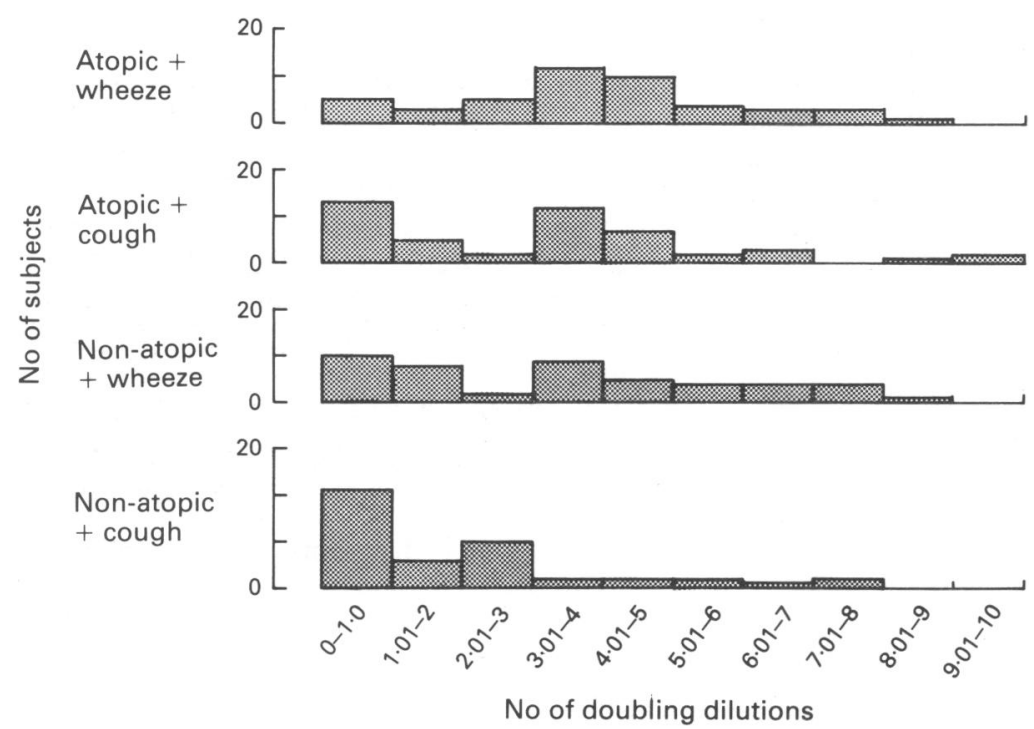

Figure 4 Range of $P D_{20}$ demonstrated by each subject over the course of 12 months expressed in doubling dilutions of methacholine.

troublesome symptom is not clearly understood, although it is often included as a symptom of childhood asthma. Thus we were eager to study subjects with cough as a sole symptom. We selected our subjects using a parent administered questionnaire, which inquired into the presence in the past 12 months of specific symptoms. We were thus able not only to avoid the predetermination of what was, or was not, asthma, but also to include in the study children with symptoms ranging in severity from mild to frankly asthmatic.

In this study, short term repeatability of the challenge procedure was found to be within $1 \cdot 3$ doubling doses of methacholine, which compares favourably with the findings of other workers using the method of Yan. ${ }^{13}$ It was essential that, if inferences were to be made from our findings on the long term variability of methacholine responsiveness, great care was taken to ensure that the techniques used for challenge testing remained as repeatable as possible throughout the study period. Each child was tested by the same investigator at each visit, unless that investigator was unavailable due to sickness, when she was replaced by the principal investigator. Each child was tested at the same time of day on each occasion in order to exclude any effect of diurnal variation, and in the same room, to minimise environmental influences. Antiasthma medication was withheld as described, and the children were rested for 10 minutes before testing. Fresh solutions of methacholine were prepared weekly, in concentrations calculated specifically for each nebuliser and the investigator using it.

Because of the nature of the study, we obtained at least $12 \mathrm{PD}_{20}$ values on all but 11 subjects and our analysis could thus be based on data collected over a 12 month period. This had the benefit of lessening the influence of the factors that can affect individual measurements of bronchial responsiveness and therefore strengthening the analyses. In spite of this, the relationship between BHR, atopy, and respiratory symptoms remained complex. Eleven per cent of those subjects with both atopy and wheeze never, at any time, demonstrated BHR, and for those demonstrating either atopy or wheeze this proportion rose to $64 \%$ and $69 \%$ respectively. These findings confirm those of Pattemore et al who found that $42 \cdot 1 \%$ of children reported to have wheezed within the past month did not demonstrate BHR to histamine. ${ }^{15}$ Similarly for atopy, in random population studies Welty et al ${ }^{18}$ and Woolcock et al ${ }^{19}$ showed no association between skin test reactivity and non-specific airways responsiveness. In asthmatic populations, Cookcroft et al did, ${ }^{20}$ and Bryant and Burns ${ }^{14}$ did not demonstrate the association of atopy with enhanced levels of bronchial responsiveness. Thus BHR appears to be an unreliable predictor of wheeze and atopy.

This study enables us to examine the relationship between $B H R$ and respiratory symptoms in these children, selected on the basis of current symptoms. As many as $40 \%$ of asthmatic subjects who have experienced symptoms within the past 12 months do not demonstrate BHR, and approximately one third of positive responders to bronchial challenge in population surveys are asymptomatic. ${ }^{5-7} 1521$ These findings may be explained by the complex genetic and environmental determinants of airways responsiveness, and by the heterogeneity of the mechanisms involved. The latter include airway wall thickening leading to loss of interdependence of the airways from the surrounding alveoli and the encroachment of folds of epithelium into the bronchial lumen, smooth muscle hypertrophy, epithelial damage, disordered contractile properties of smooth muscle, exaggeration of the cholinergic mechanisms, the increased production of chemical mediators which recruit inflammatory cells, and the so called second wave mediators triggered by those inflammatory cells. ${ }^{22}$

Other factors that have been suggested to influence levels of responsiveness include baseline airway function, ${ }^{23}$ and exposure to 
respiratory tract virus infection, ${ }^{24}$ allergens, ${ }^{25}$ and tobacco smoke. ${ }^{26}$ These confounding environmental variables could influence indices of responsiveness, making a single measurement and any assumption made upon it unreliable.

Over prolonged periods of time, bronchial responsiveness has been described as being a stable phenomenon. ${ }^{27}$ However, the findings of the present study would seem to support those of Josephs et al, who found that airways responsiveness in the clinical setting can vary considerably. ${ }^{13}$ In this study, $\mathrm{PD}_{20}$ was found to vary by up to nine doubling doses of methacholine in individual subjects over a 12 month period, one third of subjects demonstrating a variation of $>4$ doubling doses. As many subjects demonstrated levels of bronchial responsiveness near or above the upper limit measured, and indeed, $48(25 \cdot 8 \%)$ children were never hyperresponsive, it would have been possible for only the most responsive subjects to exhibit the maximum degrees of variability in $\mathrm{PD}_{20}$, and thus these figures are likely to underestimate the variability in $\mathrm{PD}_{20}$ that would be found if testing were to be performed over a greater range of methacholine concentrations.

As in the longitudinal study performed by Josephs $e t a l,{ }^{13}$ which included as subjects both children and adults, visual examination of the charted data failed to demonstrate a temporal relationship between $\mathrm{PD}_{20}$ and the state of asthma described by level of PEF, day to day and diurnal variability in PEF, and symptom score. It would seem that while a broad relationship does exist between both atopy and wheeze and BHR, in individuals levels of bronchial responsiveness can vary greatly, and at any particular moment in time there is little correlation between $\mathrm{PD}_{20}$ methacholine and the severity of asthma, whether measured in terms of symptoms or changes in PEF ${ }^{8}$ Due to the problems posed by the large number of subjects participating in this study and their clinical heterogeneity, combined with the lack of evidence of any relationship yielded by visual inspection of the charted data, we did not analyse the data from the complete cohort for temporal relationships between symptoms and changes in PEF and bronchial responsiveness. However, such analyses on selected children will form the basis of a further publication.

Although measurement of bronchial responsiveness has useful applications as a research tool, and may be able to predict those subjects at risk of accelerated decline in lung function, ${ }^{28}$ its lack of correlation with the clinical state of asthma and its variability over time make it less suitable for use as a test for diagnosis, assessment of treatment requirement and determination of prognosis, especially in children. Already, the small number of longitudinal studies in existence that incorporate responsiveness measurements have altered our views on the relevance of BHR to airways disease. Further studies, particularly in the early years of life, are greatly needed to establish the significance of BHR in relation to the range of diseases of childhood which are currently encompassed under the single diagnostic label of asthma.
The authors would like to thank Sandra Smith and Sue Cook, who made this work possible. We would also like to thank the British Lung Foundation and the National Asthma Campaign for their funding and support.

1 Clifford RD, Radford M, Howell JB, Holgate ST. Prevalence of respiratory symptoms among 7 and 11 year old
schoolchildren and the association with asthma. Arch Dis schoolchildren and the
Child 1989;64:1118-25.

2 Gregg I. Epidemiological aspects. In: Clark TJH, Godfrey S, eds. Asthma. London: Chapman and Hall, 1983:242-84.

3 Juniper EP, Frith PA, Hargreave FE. Airway responsiveness to histamine and methacholine: relationship to minimum treatment to control symptoms of asthma. Thorax 1981;36: 575-9.

4 Woolcock AJ, Peat JK, Salome CM, et al. Prevalence of bronchial hyperresponsiveness and asthma in a rural adult population. Thorax 1987; 42:361-8.

5 Hopp RJ, Bewtra AK, Nair NM, Watt GD, Townley RG. Methacholine inhalation challenge studies in a selected
paediatric population. Am Rev Respir Dis 1986;134:994-8. 6 Salome CM, Peat JK, Britton WJ, Woolcock AJ. Bronchial hyperresponsiveness in two populations of Australian hyperresponsiveness in two populations of Australian
schoolchildren. I. Relation to respiratory symptoms and diagnosed asthma. Clinical Allergy 1987;17:271-82.

7 Burney PGJ, Britton JR, Chinn S, et al. Descriptive epidemiology of bronchial reactivity in an adult population: results from a community survey. Thorax 1987;42:38-44.

8 Josephs LK, Gregg I, Holgate ST. Does non-specific bronchial responsiveness indicate the severity of asthma? Eur Respir 7 1990;3:220-7.

9 Strachan DP. Do chesty children become chesty adults? Arch Dis Child 1990;65:161-2.

10 Yan K, Salome CM, Woolcock AE. Rapid method for measurement of bronchial responsiveness. Thorax 1983;38: $760-5$

11 Britton JR, Mortagy A, Tattersfield AE. Histamine challenge testing: comparison of three methods. Thorax 1986;41: 128-32.

12 Lowhagen $O$, Lindholm NB. Short-term and long-term variation in bronchial response to histamine in asthmatic patients. European fournal of Respiratory Disease 1983;64: patients.

13 Josephs LK, Gregg I, Mullee MA, Holgate ST. Non-specific bronchial reactivity and its relationship to the clinical bronchial reactivity and its relationship to the clinical
expression of asthma. Am Rev Respir Dis 1989;140:350-7.

14 Bryant DH, Burns MW. The relationship between bronchial histamine reactivity and atopic status. Clinical Allergy 1976; 6:373-81.

15 Pattemore PK, Asher MI, Harrison AC, Mitchell EA, Rea $\mathrm{HH}$, Stewart AW. The interrelationship among bronchial hyperresponsiveness, the diagnosis of asthma, and asthma symptoms. Am Rev Respir Dis 1990;142:549-54.

6 Clough JB, Williams JD, Holgate ST. Effect of atopy on the natural history of symptoms, peak expiratory flow and bronchial responsiveness in 7 and 8 year old children with cough and wheeze; a 12 month longitudinal study. Am Rev Respir Dis 1991;143:755-60.

17 Bland JM, Altman DG. Statistical methods for assessing agreement between two methods of clinical measurement. Lancet 1986; i:307-10.

18 Welty C, Weiss ST, Tager IB. The relationship of airways responsiveness to cold air, cigarette smoking, and atopy to respiratory symptoms and pulmonary function in adults. respiratory symptoms and pulmonary

19 Woolcock A J, Colman MH, Jones MW. Atopy and bronchial reactivity in Australian and Melanesian populations. reactivity in Australian and
Clinical Allergy 1978;8:155-64.

20 Cookcroft DW, Ruffin RE, Frith PA. Determinants of allergen-induced asthma: dose of allergen, circulating IgE antibody concentration, and bronchial responsiveness to inhaled histamine. Am Rev Respir Dis 1979;120:1053-8.

21 Sears MR, Jones DT, Holdaway MD, et al. Prevalence of bronchial reactivity to inhaled methacholine in New Zealand children. Thorax 1986;41:283-9.

22 Holgate ST, Beasley R, Twentyman OP. The pathogenesis and significance of bronchial hyperresponsiveness in airways disease. Clin $S_{c i}$ 1987;73:561-72.

23 Tattersfield AE. Relationship of resting airway calibre to measurements of airways responsiveness in man. In: Hargreave FE, Woolcock AJ, eds. Airways responsiveness; measurement and interpretation. Mississauga, Canada: Astra Pharmaceuticals, 1985:94-103.

24 Empey DW, Laitinen LA, Jacobs L, et al. Mechanisms of bronchial hyperreactivity in normal subjects after upper respiratory tract infection. Am Rev Respir Dis 1976;113: 131-9.

25 Platts-Mills T, Tovey E, Mitchell B, et al. Reduction of bronchial hyperreactivity during prolonged allergen avoidance. Lancet 1982;ii:675-8.

26 Taylor RG, Joyce $H$, Gross E. Bronchial reactivity to inhaled histamine and annual rate of decline in $\mathrm{FEV}_{1}$ in male smokers and ex-smokers. Thorax 1985;40:9-16.

27 Townley RG, Bewtra AK, Nair NM, et al. Methacholine inhalation challenge studies. $f$ Allergy Clin Immunol 1979; 64:569-74.

28 O'Connor GT, Sparrow D, Weiss ST. The role of allergy and non-specific airway hyperresponsiveness in the pathogenesis of chronic obstructive pulmonary disease. Am Rev Respir Dis 1989;140:225-52. 